Article

\title{
Potassium Ferrite as Heterogeneous Photo-Fenton Catalyst for Highly Efficient Dye Degradation
}

\author{
Xinghui Zhang ${ }^{1}$, Zhibin Geng ${ }^{1}$, Juan Jian ${ }^{2}$, Yiqiang He ${ }^{1}$, Zipeng $\mathrm{Lv}^{1}$, Xinxin Liu ${ }^{3}{ }^{\mathbb{D}}$ and \\ Hongming Yuan ${ }^{1, *}$ \\ 1 State Key Laboratory of Inorganic Synthesis and Preparative Chemistry, College of Chemistry, Jilin \\ University, Changchun 130012, China; zhangxinghuih@163.com (X.Z.); gengzb14@mails.jlu.edu.cn (Z.G.); \\ yiqianghe199510@163.com (Y.H.); lvzp17@mails.jlu.edu.cn (Z.L.) \\ 2 Key Laboratory of Preparation and Applications of Environmental Friendly Material of the Ministry of \\ Education, College of Chemistry, Jilin Normal University, Changchun 130103, China; \\ jianjuan1528241015@163.com \\ 3 Institute of Catalysis for Energy and Environment, College of Chemistry and Chemical Engineering, \\ Shenyang Normal University, Shenyang 110034, China; liuxinxin1114@163.com \\ * Correspondence: hmyuan@jlu.edu.cn; Tel.: +86-0431-8516-8318
}

Received: 18 January 2020; Accepted: 3 March 2020; Published: 4 March 2020

\begin{abstract}
In this work, hexagon-shaped potassium ferrite $\left(\mathrm{K}_{2} \mathrm{Fe}_{4} \mathrm{O}_{7}\right)$ crystals with different sizes were prepared using the hydrothermal method. The crystals showed a narrow band gap of $1.44 \mathrm{eV}$, revealed by UV-visible diffuse reflectance spectroscopy, and was thus used as a heterogeneous Fenton catalyst to degrade methylene blue $(\mathrm{MB})$ and crystal violet $(\mathrm{CV})$ in the presence of green oxidant $\mathrm{H}_{2} \mathrm{O}_{2}$ under visible-light irradiation. Among the investigated crystals, the as-prepared one with an average size of $20 \mu \mathrm{m}$ (KFO-20) exhibited better photocatalytic activity due to its high surface area. When it was used as a photo-Fenton catalyst, 100\% MB and 92\% CV were degraded within 35 min. Moreover, the catalyst maintained high photocatalytic activity and was stable after four continuous cycles. The trapping experiments showed that the active hydroxyl radical $(\cdot \mathrm{OH})$ was dominant in the photo-Fenton reaction. Therefore, this new photo-Fenton catalyst has great potential for the photocatalytic degradation of dye contaminants in water.
\end{abstract}

Keywords: $\mathrm{K}_{2} \mathrm{Fe}_{4} \mathrm{O}_{7}$; visible light; Fenton catalyst; degradation; methylene blue and crystal violet

\section{Introduction}

Dyes are widely used in many industries, including textiles, printing, pulp, and paper. However, they also cause great environmental pollution that threatens public health due to their complicated constitution and high chemical stability. With the rapid development of the global economy, it is estimated that each year almost $2 \times 10^{5}$ tons of dyes are discharged directly into lakes, rivers, and groundwater [1-4]. Therefore, dye treatment in water systems is increasingly important.

Over the past few decades, many wastewater-treatment technologies have been developed for the removal or degradation of dye contaminants, such as traditional biological treatments, adsorption, coagulation/flocculation, membrane separation, precipitation, ion exchange, and advanced oxidation processes (AOPs). Among these methods, AOPs that include photochemical, catalytic, sonochemical, ozone, electrochemical, and Fenton oxidation can convert or degrade such contaminants into small molecules [5-7]. In particular, photo-Fenton oxidation has been proven to be highly effective for dye treatments [8,9]. However, homogeneous photo-Fenton technology exhibits limitations such as loss of catalysts and large iron sludge. To overcome these drawbacks, one potential strategy is using heterogeneous photo-Fenton catalysts to degrade dye contaminants. So far, several iron oxides and 
iron hydroxides utilised as photo-Fenton catalysts, such as $\mathrm{Fe}_{3} \mathrm{O}_{4}, \alpha-\mathrm{Fe}_{2} \mathrm{O}_{3}, \alpha-\mathrm{FeOOH}$, and $\beta-\mathrm{Fe}_{2} \mathrm{O}_{3}$, have been used to catalyse or degrade various kinds of dye molecules due to their good photocatalytic activity, stable structure, and narrow band gap [10-14]. The catalytic activity of metal oxides is closely related to the crystal orientation, crystallinity, nanostructure, morphology, particle size, and surface properties of the material [15-20]. To further enhance their catalytic activity, some with nanometre sizes were prepared using nanotechnology $[11,21,22]$. Other transition metals were introduced into their structure to improve their catalytic activity [23-27]. Recently, iron oxide and carbon composites have also been used to effectively degrade organic dyes [28-33].

At present, there is an urgent need for low-cost, resource-friendly, stable iron-based heterogeneous Fenton catalysts for the degradation of dye contaminants in wastewater. The Fenton catalytic properties of iron oxides are strongly dependent on the crystal structural characters, band gap, and oxidation states of iron ions at octahedral and tetrahedral sites. All of the iron oxides mentioned above are constructed from iron octahedral and tetrahedral unites, and adopt either corundum or spinel structures. The search for an iron-based heterogeneous photo-Fenton catalyst with a new crystal structure is a key step towards more effectively degrading dye contaminants. Recently, we successfully synthesised potassium ferrite $\left(\mathrm{K}_{2} \mathrm{Fe}_{4} \mathrm{O}_{7}\right)$ using the hydrothermal process [34]. This environmentally friendly iron oxide exhibited superhigh ion conductivity and excellent thermal stability. Its 3D structure consisted of octahedral $\mathrm{FeO}_{6}$ and tetrahedral $\mathrm{FeO}_{4}$ with shared vertices and edges. Therefore, the structure may be developed for use as a powerful candidate for a heterogeneous photo-Fenton catalyst for the degradation of dye molecules.

In this work, we prepared the hexagonal $\mathrm{K}_{2} \mathrm{Fe}_{4} \mathrm{O}_{7}$ crystals with different sizes using the hydrothermal method. Its band gap was determined by UV-visible diffuse reflectance spectroscopy. Methylene blue $(\mathrm{MB})$ and crystal violet $(\mathrm{CV})$ were selected as models to evaluate the catalytic activity of this iron oxide under photo-Fenton conditions. We then studied the effect of $\mathrm{pH}$ value, the concentration of hydrogen peroxide, and particle size on MB degradation. We also evaluated the reusability and stability of the catalyst.

\section{Results and Discussion}

\subsection{Characterisation}

SEM images of KFO-20 (Figure 1 a, b), KFO-80 (Figure 1 c, d), and KFO-180 (Figure 1 e, f) show that the obtained $\mathrm{K}_{2} \mathrm{Fe}_{4} \mathrm{O}_{7}$ crystals each had the same hexagonal shape and smooth surface except for crystal size. The powder XRD patterns of KFO-20, KFO-80, and KFO-180 are shown in Figure 2, where it is clear that all diffraction peaks were consistent with that of $\mathrm{K}_{2} \mathrm{Fe}_{4} \mathrm{O}_{7}$ reported previously [34]. This indicates that each sample's structure remained intact and was in a pure phase. Studies showed that, as a result of higher crystallinity, there were fewer lattice defects, which are more conductive to the conduction of the charge carrier. This result is consistent with photoluminescence (PL).

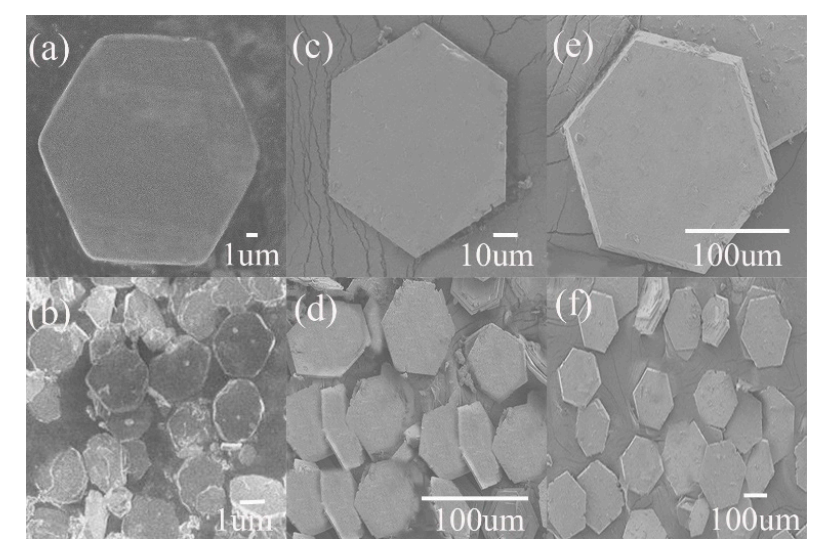

Figure 1. SEM images of (a, b) KFO-20, (c, d) KFO-80, and (e, f) KFO-180. 


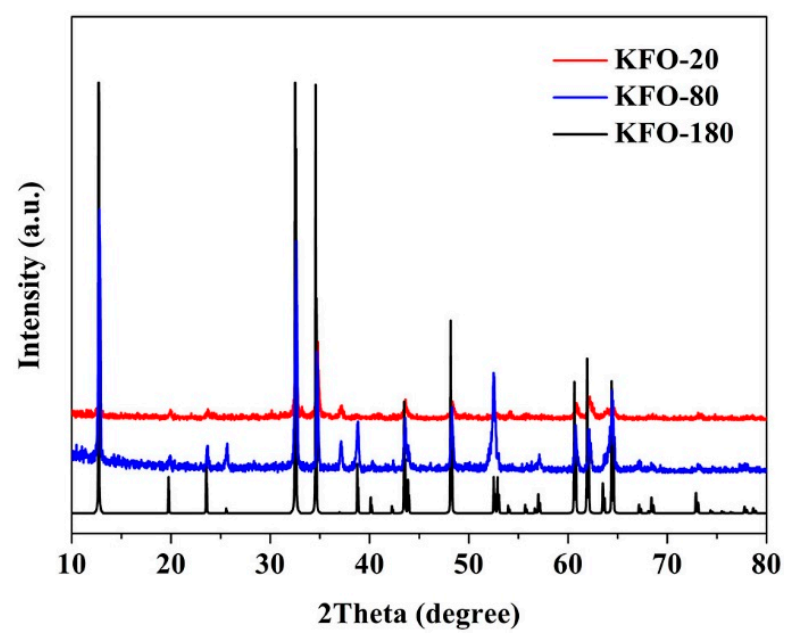

Figure 2. Powder XRD patterns of KFO-20, KFO-80, and KFO-180.

The band gaps of three samples were determined by UV-visible diffuse reflectance spectroscopy measurement. They exhibited the same broad absorption with an absorption edge at about $858 \mathrm{~nm}$ (Figure 3a). Band-gap energy was calculated as $1.44 \mathrm{eV}$ according to the equation $\mathrm{Eg}=\mathrm{hc} / \lambda$, where $\mathrm{Eg}$ is the energy band gap (eV) and $\mathrm{hc}=1240 \mathrm{eV}$ [35]. This narrow band gap was less than those of $\mathrm{Fe}_{3} \mathrm{O}_{4}$ [14], $\alpha-\mathrm{Fe}_{2} \mathrm{O}_{3}$ [12], $\alpha-\mathrm{FeOOH}$ [12], and $\mathrm{NiFe}_{2} \mathrm{O}_{4}$ [11], and was thus a favourable candidate to effectively degrade dye molecules in photo-Fenton catalytic processes under low-energy visible-light irradiation. The comparison of various catalytic systems for MB degradation under different photo-Fenton processes is shown in Table 1.
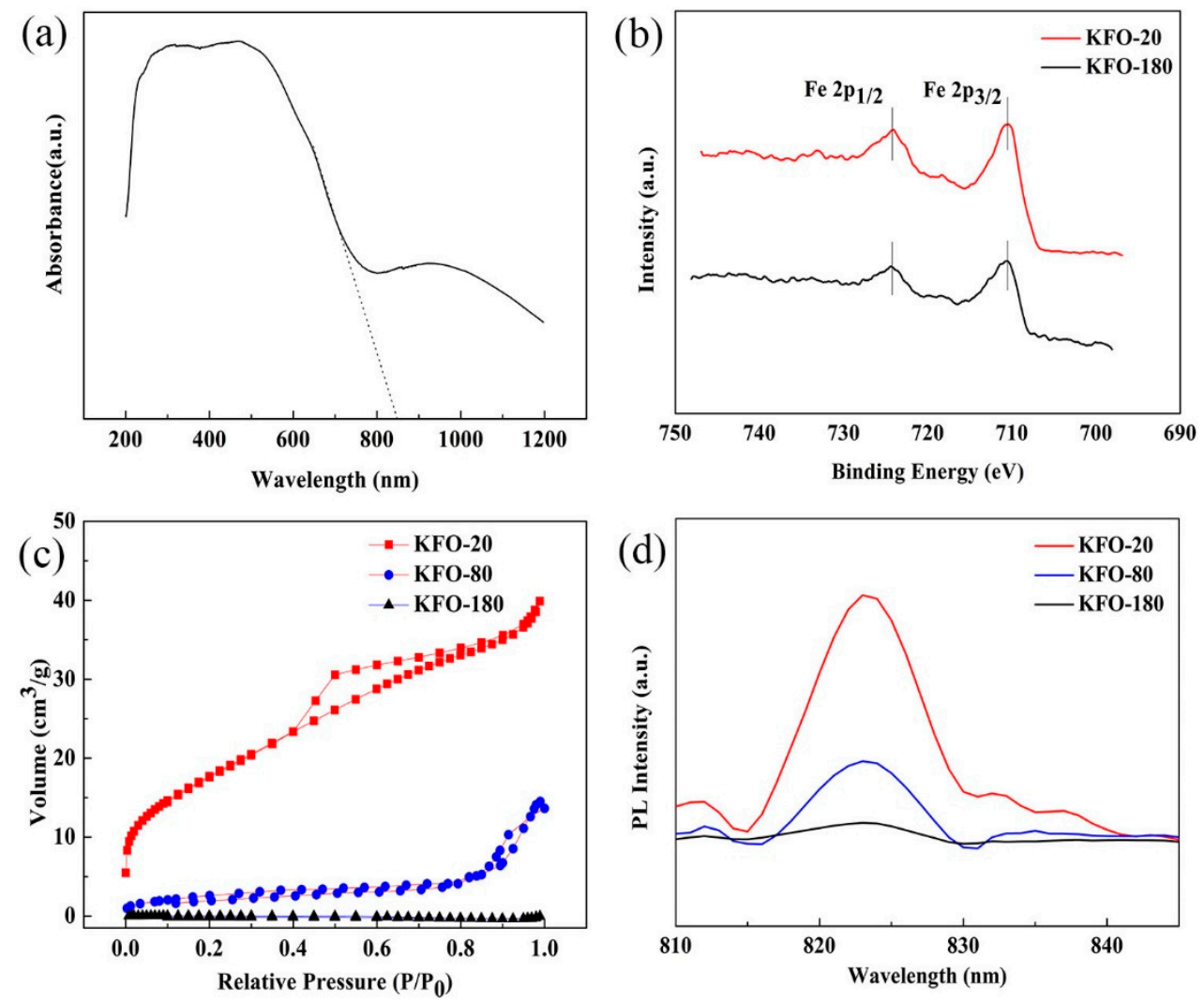

Figure 3. (a) UV-visible diffuse reflectance spectroscopy; (b) XPS spectra of $\mathrm{Fe} 2 \mathrm{p}_{1 / 2}$ and $\mathrm{Fe} 2 \mathrm{p}_{3 / 2}$ for KFO-20 and KFO-180; (c) $\mathrm{N}_{2}$ adsorption-desorption isotherms measured at 77K of KFO; and (d) photoluminescence (PL) spectra of KFO. 
Table 1. Comparison of various catalytic systems for methylene blue (MB) degradation under different photo-Fenton processes.

\begin{tabular}{|c|c|c|c|c|}
\hline Catalyst & Reaction Condition & Degradation Rate & Time & Reference \\
\hline $\mathrm{NiFe}_{2} \mathrm{O}_{4}$ & $\begin{array}{l}{[\text { Catalyst }]=0.2 \mathrm{~g} / \mathrm{L},\left[\mathrm{H}_{2} \mathrm{O}_{2}\right]=5 \mathrm{mM},} \\
{[\mathrm{MB}]=30 \mathrm{mg} / \mathrm{L} \text { and light irradiation }}\end{array}$ & $98.5 \%$ & $50 \mathrm{~min}$ & [11] \\
\hline $\mathrm{Fe}_{3} \mathrm{O}_{4}$ & $\begin{array}{c}{[\text { Catalyst }]=4 \mathrm{~g} / \mathrm{L},\left[\mathrm{H}_{2} \mathrm{O}_{2}\right]=50 \mathrm{mM},} \\
{[\mathrm{MB}]=100 \mathrm{mg} / \mathrm{L}, \text { and } \mathrm{UV} \text { irradiation }} \\
{[\text { Catalyst }]=0.025 \mathrm{~g} / \mathrm{L}}\end{array}$ & $20 \%$ & $60 \mathrm{~min}$ & [14] \\
\hline$\alpha-\mathrm{Fe}_{2} \mathrm{O}_{3}$ & $\begin{aligned} {\left[\mathrm{H}_{2} \mathrm{O}_{2}\right] } & =1.10 \mathrm{mM},[\mathrm{MB}]=40 \mathrm{mg} / \mathrm{L} \\
& \text { and UV irradiation }\end{aligned}$ & $94.7 \%$ & $80 \mathrm{~min}$ & [12] \\
\hline $\mathrm{CuFe}_{2} \mathrm{O}_{4}$ & $\begin{array}{l}{[\text { Catalyst }]=0.1 \mathrm{~g} / \mathrm{L},\left[\mathrm{H}_{2} \mathrm{O}_{2}\right]=20 \mathrm{mM},} \\
{[\mathrm{MB}]=30 \mathrm{mg} / \mathrm{L} \text { and light irradiation }}\end{array}$ & $80 \%$ & $80 \mathrm{~min}$ & [36] \\
\hline $\mathrm{ZnO}$ & $\begin{array}{l}{[\text { Catalyst }]=0.02 \mathrm{~g} / \mathrm{L},\left[\mathrm{H}_{2} \mathrm{O}_{2}\right]=5 \mathrm{mM},} \\
{[\mathrm{MB}]=20 \mathrm{mg} / \mathrm{L} \text { and light irradiation }}\end{array}$ & $4.1 \%$ & $60 \mathrm{~min}$ & [37] \\
\hline $\mathrm{TiO}_{2}$ & $\begin{array}{c}{[\text { Catalyst }]=1.0 \mathrm{~g} / \mathrm{L},[\mathrm{MB}]=50 \mathrm{mg} / \mathrm{L}} \\
\text { and light irradiation }\end{array}$ & $30 \%$ & $60 \mathrm{~min}$ & [38] \\
\hline $\mathrm{K}_{2} \mathrm{Fe}_{4} \mathrm{O}_{7}$ & $\begin{array}{l}{[\text { Catalyst }]=0.03 \mathrm{~g} / \mathrm{L},\left[\mathrm{H}_{2} \mathrm{O}_{2}\right]=5 \mathrm{mM},} \\
{[\mathrm{MB}]=20 \mathrm{mg} / \mathrm{L} \text { and light irradiation }}\end{array}$ & $100 \%$ & $35 \mathrm{~min}$ & This article \\
\hline
\end{tabular}

The XPS spectra of KFO-20 and KFO-180 are shown in Figure 3b. There were two obvious peaks with binding energies of 724.2 and $711.3 \mathrm{eV}$, which corresponded, respectively, to Fe $2 \mathrm{p}_{1 / 2}$ and Fe $2 p_{3 / 2}$. XPS results were in good agreement with those of the reported crystal [34], suggesting that the oxidation state of iron ion in the as-prepared KFO was +3 .

The Brunauer-Emmett-Teller (BET) surface area was measured via nitrogen adsorption-desorption experiments. As shown in Figure 3c, the adsorption-desorption isotherms of KFO corresponded to Type IV on the basis of the Brunauer-Deming-Teller classification [39,40]. The specific surface area of KFO-20, KFO-80, and KFO-180 was 63.79, 9.63, and $0.42 \mathrm{~m}^{2} / \mathrm{g}$, respectively, which increased with the decrease of particle size. In this work, we found that crystallinity contributed little to MB degradation comparing to the specific surface area.

The photoluminescence (PL) spectrum was used to investigate the recombination behaviour of photogenerated electrons and holes in KFO-20, KFO-80, and KFO-180. The PL emission spectra of the three crystals at an excitation wavelength of $475 \mathrm{~nm}$ are shown in Figure 3d. A strong peak near $820 \mathrm{~nm}$ caused by the band-band PL phenomenon was observed, which was approximately equal to the band-gap energy of KFO $(1.44 \mathrm{eV})$. However, peak intensity decreased with the decrease of crystal size due to shorter diffusion distance, suggesting that KFO-20 with a lower recombination rate of photogenerated electron-hole pair was expected to have higher photocatalytic activity.

\subsection{Photo-Fenton MB Degradation}

We first selected KFO-20 as a Fenton catalyst to perform the degradation of $\mathrm{MB}$ at $\mathrm{pH}=2,20 \mathrm{mg} / \mathrm{L}$ of $\mathrm{MB}$ at room temperature in the absence and presence of visible light, and with or without hydrogen peroxide. Degradation results are shown in Figure 4a. With visible-light radiation in the presence of KFO-20 and $\mathrm{H}_{2} \mathrm{O}_{2}$ (curve A), 100\% of the $\mathrm{MB}$ was degraded within 35 min. However, under darker conditions, $46 \%$ of the MB was degraded within the same timeframe (curve B), indicating that its Fenton catalytic activity was significantly enhanced by introducing visible light. Only $12 \%$ of $\mathrm{MB}$ was degraded when the catalyst was not employed due to the self-sensitisation of $\mathrm{MB}$ (curve $\mathrm{C}$ ). $\mathrm{MB}$ concentration had no apparent change when without hydrogen peroxide (curve D), confirming that MB degradation was attributed to the photo-Fenton process. The catalytic activity of the catalyst was superior to conventional photo-Fenton catalysts mentioned above [11-14]. Therefore, it can be concluded that the excellent catalytic activity of this iron oxide is assigned to its structural feature and the nature of the iron ion. 
(a)

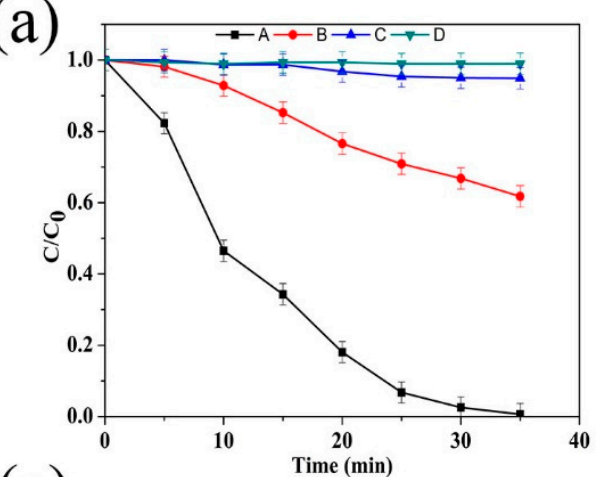

(c)

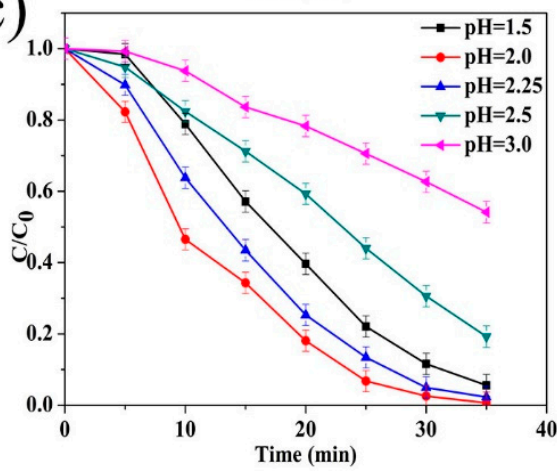

(b)
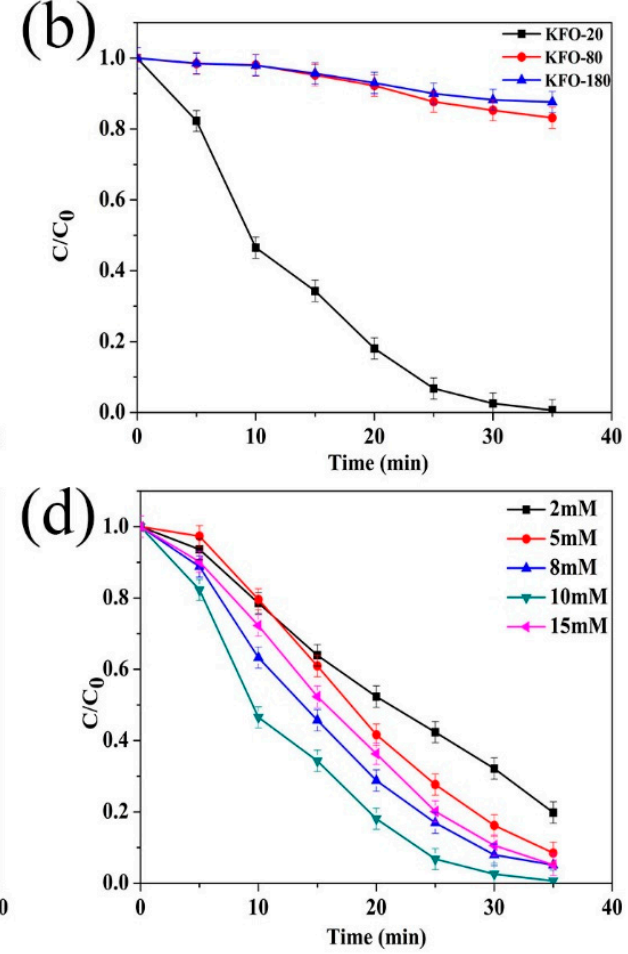

Figure 4. (a) Degradation efficiency of methylene blue (MB) under different conditions. $\mathrm{A}: \mathrm{MB}+$ $\mathrm{KFO}-20+\mathrm{H}_{2} \mathrm{O}_{2}+$ light; $\mathrm{B}: \mathrm{MB}+\mathrm{KFO}-20+\mathrm{H}_{2} \mathrm{O}_{2} ; \mathrm{C}: \mathrm{MB}+\mathrm{H}_{2} \mathrm{O}_{2}+$ light; $\mathrm{D}: \mathrm{MB}+\mathrm{KFO}-20$ + light; (b) degradation efficiency of $\mathrm{MB}$ using $\mathrm{KFO}$ catalysts with different sizes; (c) degradation efficiency of $\mathrm{MB}$ at different $\mathrm{pH}$ values; (d) degradation efficiency of $\mathrm{MB}$ at various $\mathrm{H}_{2} \mathrm{O}_{2}$ concentrations. Reaction conditions: $\mathrm{MB}$ concentration, $20 \mathrm{mg} / \mathrm{L}$; $\mathrm{KFO}$ mass, $30 \mathrm{mg} ; \mathrm{H}_{2} \mathrm{O}_{2}, 10 \mathrm{mM}$; reaction time, $35 \mathrm{~min}$.

\subsubsection{Effect of Catalyst Size}

In general, the catalytic activity of heterogeneous Fenton catalysts was proportional to their specific surface area. A larger specific surface area can provide more active sites for a photo-Fenton catalytic process. Therefore, we investigated the effect of different KFO sizes on the degradation of MB under the same conditions. As shown in Figure $4 \mathrm{~b}$, about $34 \%$ and $24 \%$ of degradation were achieved within $35 \mathrm{~min}$ for KFO-80 and KFO-180, respectively, due to their different specific surface areas, which was consistent with the results of BET surface-area measurements.

\subsubsection{Effect of $\mathrm{pH}$ Value}

The Fenton oxidation reaction was sensitive to the $\mathrm{pH}$ value of the reacting solution. Therefore, the effect of the initial $\mathrm{pH}$ value on the degradation of $\mathrm{MB}(20 \mathrm{mg} / \mathrm{L})$ was investigated by using the KFO-20 photo-Fenton catalyst. Figure $4 \mathrm{c}$ gives the removal efficiency of $\mathrm{MB}$ at different $\mathrm{pH}$ values within $35 \mathrm{~min}$. At $\mathrm{pH}=1.5$, about $98 \%$ of $\mathrm{MB}$ degradation was obtained, and $100 \%$ of $\mathrm{MB}$ was degraded when we increased the $\mathrm{pH}$ value to 2.0 because excess $\mathrm{H}^{+}$acted as a scavenger for the hydroxyl radical $(\cdot \mathrm{OH})$, as shown in Equation (1) [40]. As $\mathrm{pH}$ value increased, the removal percentage decreased to $90 \%$ at $\mathrm{pH}=2.5$. Therefore, the photo-Fenton catalyst can be used to effectively degrade $\mathrm{MB}$ in the $\mathrm{pH}$ range of $1.5-2.5$.

$$
\cdot \mathrm{OH}+\mathrm{H}^{+}+\mathrm{e}^{-} \rightarrow \mathrm{H}_{2} \mathrm{O}
$$

\subsubsection{Effect of $\mathrm{H}_{2} \mathrm{O}_{2}$ Dose}

In the heterogeneous Fenton reaction, redox cycling between $\mathrm{Fe}^{3+}$ and $\mathrm{Fe}^{2+}$ was achieved by $\mathrm{H}_{2} \mathrm{O}_{2}$. Figure $4 \mathrm{~d}$ shows the effect of the $\mathrm{H}_{2} \mathrm{O}_{2}$ concentration on $\mathrm{MB}$ degradation in the presence of the KFO-20 catalyst and visible light. MB degradation increased to $100 \%$ when the molar concentration of 
$\mathrm{H}_{2} \mathrm{O}_{2}$ increased from 2 to $10 \mathrm{mM}$. This could be due to the formation of much $\cdot \mathrm{OH}$ in the photo-Fenton reaction (Equation (2)) [41]. However, $98 \%$ of $\mathrm{MB}$ was degraded at the concentration of $15 \mathrm{mM}$, because hydroperoxyl radicals (HO) that were generated through excessive $\mathrm{H}_{2} \mathrm{O}_{2}$ reacting with the $\cdot \mathrm{OH}$ did not contribute to MB degradation (Equations (3)-(5)) [40,42-46]. This scavenging effect has been observed in many photo-Fenton processes.

$$
\begin{gathered}
\mathrm{H}_{2} \mathrm{O}_{2}+h v \rightarrow 2 \cdot \mathrm{OH} \\
\mathrm{H}_{2} \mathrm{O}_{2}+\cdot \mathrm{OH} \rightarrow \mathrm{H}_{2} \mathrm{O}+\mathrm{H}_{2} \mathrm{O} \\
\mathrm{H}_{2} \mathrm{O}_{2}+\mathrm{HO}_{2} \cdot \rightarrow \mathrm{OH}+\mathrm{H}_{2} \mathrm{O}+\mathrm{O}_{2} \\
\mathrm{H}_{2} \mathrm{O}+\mathrm{HO} \cdot \rightarrow \mathrm{H}_{2} \mathrm{O}+\mathrm{O}_{2}
\end{gathered}
$$

\subsubsection{Dynamic Degradation}

In the photo-Fenton reaction system, a pseudo-first-order kinetic constant model was used to quantitatively evaluate the photocatalytic process. The rate constant was obtained by plotting $-\ln$ $\left(C / C_{0}\right)$ versus time, as shown in Figure $5 a$, where $C_{0}$ and $C$ are the initial concentration and the concentration at time $\mathrm{t}$, respectively. The specific surface area $\mathrm{S}\left(\mathrm{m}^{2} / \mathrm{g}\right)$, rate constant, and $\mathrm{k}\left(\mathrm{min}^{-1}\right)$ of KFO are shown in Table 2. The rate constants of KFO-20, KFO-80, and KFO-180 were 0.155, 0.007 and $0.006 \mathrm{~min}^{-1}$, respectively. The rate constant of KFO-20 was 26 times that of KFO-180, and the rate constant of the catalyst increased with the increase of specific surface area.
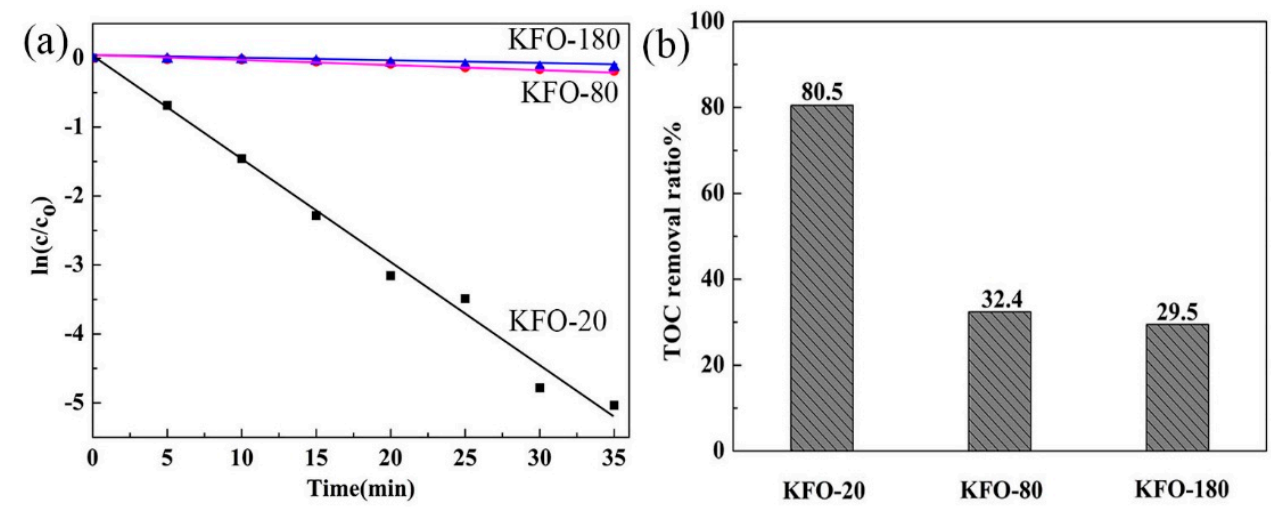

Figure 5. (a) Pseudo-first-order kinetics degradation of MB; (b) total organic carbon (TOC) removal of

\begin{tabular}{|c|c|c|}
\hline & $\mathrm{S}\left(\mathrm{m}^{2} / \mathrm{g}\right)$ & $k\left(\min ^{-1}\right)$ \\
\hline KFO-20 & 63.79 & 0.155 \\
\hline KFO-80 & 9.63 & 0.007 \\
\hline KFO-180 & 0.42 & 0.006 \\
\hline
\end{tabular}
$\mathrm{MB}$ in presence of differently sized KFOs. Reaction conditions: MB concentration, $20 \mathrm{mg} / \mathrm{L} ; \mathrm{KFO}$ mass, $30 \mathrm{mg} ; \mathrm{H}_{2} \mathrm{O}_{2}, 10 \mathrm{mM}$; reaction time, $35 \mathrm{~min}$.

Table 2. KFO specific surface area $\mathrm{S}\left(\mathrm{m}^{2} / \mathrm{g}\right)$ and rate constant $\mathrm{k}\left(\mathrm{min}^{-1}\right)$.

\subsubsection{Total Organic Carbon}

In order to determine the degree of mineralisation of $\mathrm{MB}$, the total organic carbon (TOC) removal rates of different $\mathrm{KFO}$ sizes were measured using $\mathrm{MB}$ as a substrate under the same conditions (Figure 5b). The removal rate of TOC increased with the decrease of KFO sizes. The removal rate of KFO-20 reached $80.5 \%$, which indicated that the KFO-20 effectively mineralised MB. 


\subsubsection{Universal Applicability of Catalyst}

In order to evaluate the photo-Fenton KFO catalysts for other types of dye degradation under the same conditions, experiments of crystal violet (CV) degradation were carried out using catalysts with different sizes. As shown in Figure 6a, KFO-180 and KFO-80 did not produce high degradation efficiency within $35 \mathrm{~min}$. However, $92 \%$ of CV was degraded by KFO-20. On the basis of the aforementioned results, the KFO-20 catalyst displayed the best photo-Fenton catalytic activity.
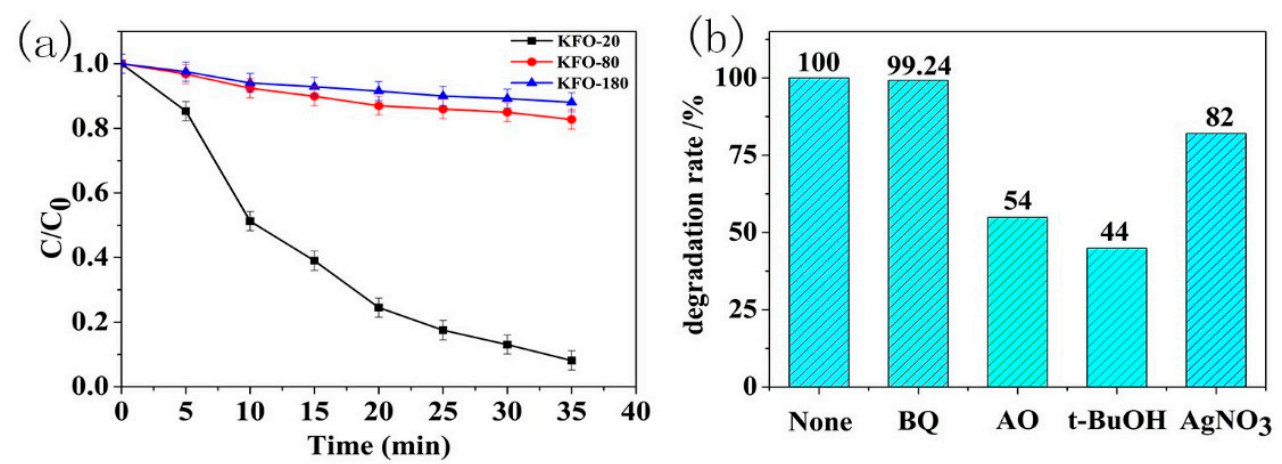

Figure 6. (a) Degradation efficiency of crystal violet (CV) with KFO catalysts at $\mathrm{pH}$ 2; (b) effects of different scavengers on $\mathrm{MB}$ degradation at $\mathrm{pH} 2$ in presence of $\mathrm{KFO}-20, \mathrm{H}_{2} \mathrm{O}_{2}$, and light.

\subsubsection{Trapping Experiments}

To determine active species that were dominant for the degradation of $\mathrm{MB}$, several scavengers, including $10 \mathrm{mmol} / \mathrm{L}$ of p-benzoquinone $(\mathrm{BQ})$, ammonium oxalate $(\mathrm{AO})$, tertiary butyl alcohol (t-BuOH), and silver nitrate $\left(\mathrm{AgNO}_{3}\right)$, were used to trap these active species; results are shown in Figure $6 \mathrm{~b}$. BQ could trap the superoxide anion $\left(\cdot \mathrm{O}_{2}^{-}\right)$. When $\mathrm{BQ}$ was added into the solution, $100 \%$ of the $\mathrm{MB}$ was degraded within $35 \mathrm{~min}$, indicating that the $\cdot \mathrm{O}_{2}{ }^{-}$radical has little contribution to the degradation process. After $\mathrm{t}-\mathrm{BuOH}$ was added as an $\cdot \mathrm{OH}$ scavenger, the degradation rate of the $\mathrm{MB}$ was $45 \%$, and the degradation process was significantly inhibited. This indicated that the $\cdot \mathrm{OH}$ radical played a key role in the degradation process. When $\mathrm{AO}$ and $\mathrm{AgNO}_{3}$ were used to capture $\mathrm{h}^{+}$and $\mathrm{e}^{-}$, respectively, $55 \%$ and $82 \%$ of the $\mathrm{MB}$ were degraded. The difference between them came from the contribution of additional $\cdot \mathrm{OH}$ radicals generated by photogenerated holes reacting with $\mathrm{H}_{2} \mathrm{O}_{2}$ (Equation (2)).

\subsection{Possible Photo-Fenton Catalytic Mechanism}

On the basis of the above experiment results, we proposed the photo-Fenton catalytic mechanism of KFO. The decomposed $\mathrm{H}_{2} \mathrm{O}_{2}$ and generated hydroxyl radicals on the surface of $\mathrm{KFO}$ particles can be described in the following reactions (Equations (2)-(7)). $\mathrm{Fe}^{3+}$ was reduced by adsorbed $\mathrm{H}_{2} \mathrm{O}_{2}$ to generate $\mathrm{Fe}^{2+}$ and peroxide hydroxyl radicals (HOO.) on the surface of a catalyst (Equation (6)). Meanwhile, HOO reacted with hydrogen peroxide in an aqueous solution to produce a highly active hydroxyl radical (.OH) (Equation (4)). The generation of $\cdot \mathrm{OH}$, which can efficiently degrade organic compounds in photo-Fenton-like reactions, can be described through the reaction between the formed $\mathrm{Fe}^{2+}$ and $\mathrm{H}_{2} \mathrm{O}_{2}$ (Equation (7)). Under visible-light irradiation, electron-hole pairs were generated on the surface of KFO (Equation (8)). Subsequently, the photogenerated electrons reduced hydrogen peroxide and reacted with dissolved oxygen to produce $\mathrm{HO} \cdot \mathrm{HO}^{-}$, and $\cdot \mathrm{O}_{2}{ }^{-}$(Equations (9) and (10)) $[44,45,47,48]$. Additional $\cdot \mathrm{OH}$ were generated by photogenerated holes that reduced water and hydrogen peroxide (Equations (11) and (12)) [44,45,47,48]. Scheme 1 gives a graphical representation of photo-Fenton MB degradation.

$$
\begin{aligned}
\mathrm{Fe}^{3+}+\mathrm{H}_{2} \mathrm{O}_{2} & \rightarrow \mathrm{Fe}^{2+}+\mathrm{HO}_{2} \cdot+\mathrm{H}^{+} \\
\mathrm{Fe}^{2+}+\mathrm{H}_{2} \mathrm{O}_{2} & \rightarrow \mathrm{Fe}^{3+}+\mathrm{HO}+\mathrm{OH}^{-} \\
\mathrm{KFO}+h v & \rightarrow \mathrm{KFO}\left(\mathrm{h}^{+}+\mathrm{e}^{-}\right)
\end{aligned}
$$




$$
\begin{gathered}
\mathrm{e}^{-}+\mathrm{H}_{2} \mathrm{O}_{2} \rightarrow \mathrm{HO}^{-}+\mathrm{HO} \\
\mathrm{e}^{-}+\mathrm{O}_{2} \rightarrow \mathrm{O}_{2}^{-} \\
\mathrm{h}^{+}+\mathrm{H}_{2} \mathrm{O} \rightarrow \mathrm{H}^{+}+\mathrm{HO} \\
\mathrm{h}^{+}+\mathrm{HO}^{-} \rightarrow \mathrm{HO} \\
\mathrm{HO}+\mathrm{MB} \rightarrow \text { degradation products } \\
\mathrm{h}^{+}+\mathrm{MB} \rightarrow \text { degradation products }
\end{gathered}
$$

Therefore, HO- and the $\mathrm{h}^{+}$hole dominantly oxidised the MB molecule (Equations (13) and (14)).

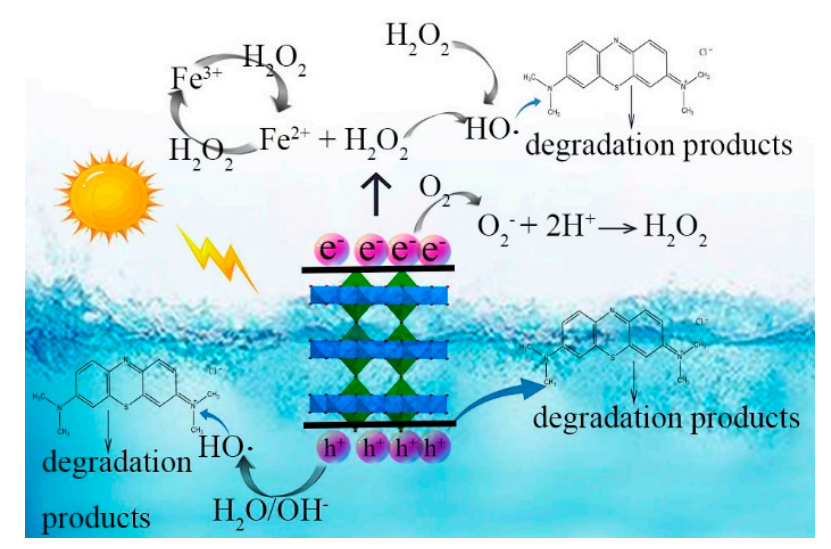

Scheme 1. MB degradation by KFO-20.

\subsection{Reusability and Chemical Stability}

From the view of industrial applications, a catalyst's chemical stability and reusability are both important. To evaluate the possibility of catalyst reuse, photo-Fenton reaction for MB degradation was successively performed using the KFO-20 catalyst (measurements are described in Supplementary Materials). As exhibited in Figure 7a, it is clearly seen that the catalytic activity of KFO-20 still remained efficient after four cycles under the same conditions. Moreover, after the reaction, the surface morphology of KFO-20 was almost indistinguishable from that of a fresh KFO-20 (Figure 7b). In addition, the powder XRD pattern of the used sample agreed with that of the as-prepared sample (Figure S1), suggesting that it had good chemical stability.
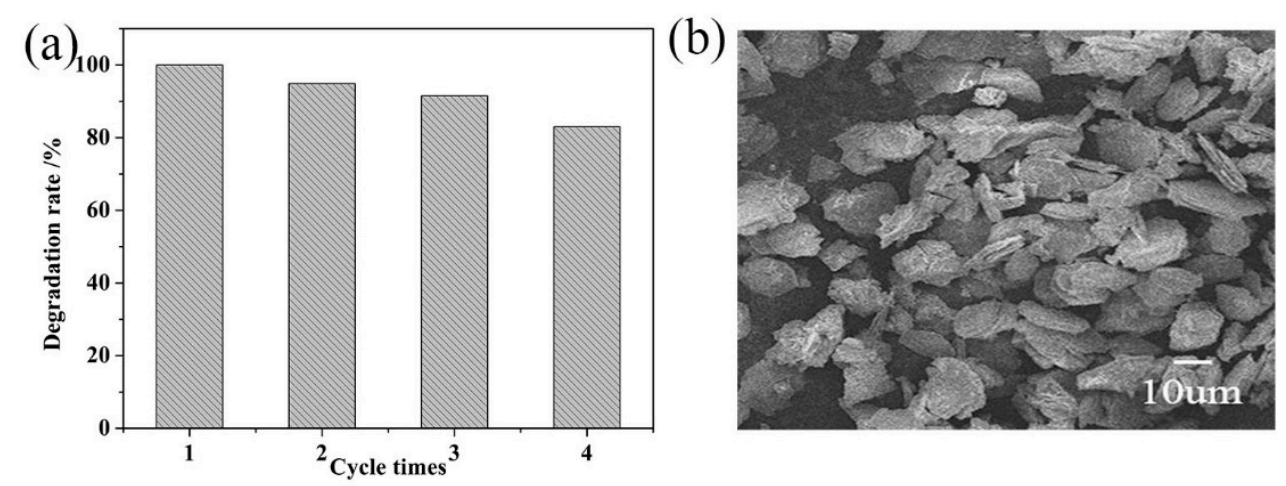

Figure 7. (a) Degradation efficiency of MB for KFO-20 at different cycles; (b) SEM image for KFO-20 after four successive cycles. 


\section{Materials and Methods}

\subsection{Materials}

Analytical-grade ferric nitrate $\left(\mathrm{FeNO}_{3} \cdot 9 \mathrm{H}_{2} \mathrm{O}\right)$, potassium hydroxide $(\mathrm{KOH})$, sodium hydroxide $(\mathrm{NaOH})$, barium sulfate $\left(\mathrm{BaSO}_{4}\right)$, ammonium oxalate $(\mathrm{AO})$, and hydrogen peroxide $\left(\mathrm{H}_{2} \mathrm{O}_{2}\right)$ were purchased from Sinopharm Chemical Reagent Co., Ltd. (Changchun, China). P-benzoquinone (BQ) was supplied by Aladdin Ltd. (Changchun, China). Methylene blue (MB) and crystal violet were obtained from Xinzhong Chemical Reagent Co., Ltd. (Changchun, China). Tertiary butyl alcohol $(\mathrm{t}-\mathrm{BuOH})$ and hydrochloric acid $(\mathrm{HCl})$ were acquired from Shanghai Runjie Chemical Reagent Co., Ltd. (Shanghai, China). Silver nitrate $\left(\mathrm{AgNO}_{3}\right)$ was purchased from Shanghai Chemical Reagent Co., Ltd. (Shanghai, China). Potassium bromide was obtained from Shanghai Macklin Biochemical Co., Ltd. (Changchun, China). All chemicals could be directly used without further treatment.

\subsection{Preparation}

KFO-20 was prepared using the hydrothermal process on the basis of our ever-reported method [34]. First, we added $4 \mathrm{~g}$ of ferric nitrate into $32 \mathrm{~mL}$ of deionised water to form a clarifying solution. We slowly added $60 \mathrm{~g}$ of potassium hydroxide into a ferric nitrate solution while stirring continuously until the colour became light brown. The mixture was directly added into a Teflon-lined stainless-steel autoclave and heated at $180^{\circ} \mathrm{C}$ for $2 \mathrm{~h}$. After cooling down to room temperature, the crystal was washed 10 times with deionised water until its $\mathrm{pH}$ was neutralised. The crystal was then dried overnight in a vacuum drying oven at $60{ }^{\circ} \mathrm{C}$. The preparation method of $\mathrm{K}_{2} \mathrm{Fe}_{4} \mathrm{O}_{7}$ with average sizes of 80 (KFO-80) and $180 \mu \mathrm{m}$ (KFO-180) can be found in our supporting information.

\subsection{Material Characterisation}

Powder XRD experiments were performed on a Rigaku D-Max 2550 diffractometer (Tokyo, Japan) with $\mathrm{Cu}-\mathrm{K} \alpha$ radiation $(\lambda=1.5418 \AA)$. SEM images were obtained on a JEOL-6700 scanning electron microscope (Tokyo, Japan). UV-visible diffuse reflectance spectroscopy was performed with a Shimadzu UV-2450 spectrometer (Kyoto, Japan) XPS analysis was performed on a VG Scienta R3000 spectrometer (New York, N. Y., USA) with $\mathrm{Al} \mathrm{K \alpha}(1486.6 \mathrm{eV})$ as the X-ray source.

\section{4. $M B$ Degradation}

The degradation of MB was carried out in the presence of visible light in a cylindrical Pyrex vessel with a PL-300 xenon lamp (Beijing China) $(\lambda>400 \mathrm{~nm})$ as the analogue sunlight source. During the experiment, the distance between light source and container was kept at $10 \mathrm{~cm}$ to ensure the same light intensity. The reaction vessel was equipped with a cooling device to ensure a constant reaction temperature. The initial experiment conditions were as follows: a mixture of $0.03 \mathrm{~g}$ of the micron scale catalyst and $100 \mathrm{~mL}$ of $\mathrm{MB}$ were stirred in dark conditions for $60 \mathrm{~min}$ to reach adsorption equilibrium. Then, $10 \mathrm{mM}$ of $\mathrm{H}_{2} \mathrm{O}_{2}(30 \% \mathrm{w} / \mathrm{v})$ was added into the solution, and the $\mathrm{pH}$ was adjusted to 2 . The $\mathrm{pH}$ value was adjusted by adding $0.1 \mathrm{M} \mathrm{HCl}$ and $0.1 \mathrm{M} \mathrm{NaOH}$. Then, $2 \mathrm{~mL}$ of the reaction solution was taken out with a $5 \mathrm{~mL}$ disposable syringe at regular intervals, and the catalyst in the solution was removed with a $0.2 \mu \mathrm{m}$ filter. The concentration of $\mathrm{MB}$ remaining in the solution was determined by UV-visible spectroscopy. The degradation rate was calculated using Equation (15), where $\mathrm{C}_{0}$ and $\mathrm{C}$ were the initial concentration and the concentration at time $t$, respectively.

$$
\mathrm{Dr}=\mathrm{C} / \mathrm{C}_{0}
$$

\section{Conclusions}

Hexagonal $\mathrm{K}_{2} \mathrm{Fe}_{4} \mathrm{O}_{7}$ crystals with different sizes were successfully prepared under hydrothermal conditions; their narrow band gap was $1.44 \mathrm{eV}$. Three KFO crystals had specific surface areas of 63.79, 9.63 , and $0.42 \mathrm{~m}^{2} / \mathrm{g}$, respectively. A small-crystal KFO-20 with a high surface area was used as a 
photo-Fenton catalyst for the degradation of $\mathrm{MB}$ and $\mathrm{CV}$ in the presence of green oxidant $\mathrm{H}_{2} \mathrm{O}_{2}$ under visible-light irradiation. The degradation rates of $\mathrm{MB}$ and $\mathrm{CV}$ reached $100 \%$ and $92 \%$ within $35 \mathrm{~min}$, respectively. Moreover, KFO-20 was shown to have good reusability and stability in the photo-Fenton degradation of $\mathrm{MB}$. The $\cdot \mathrm{OH}$ radical was dominant in the photo-Fenton catalytic reaction. Combining the KFO catalyst and carbon materials with a catalyst of nanometre size could significantly enhance heterogeneous Fenton catalytic activity and be used as an efficient and stable catalyst for the removal of dye contaminants in wastewater in the future.

Supplementary Materials: The following are available online at http://www.mdpi.com/2073-4344/10/3/293/s1, Figure S1: Powder XRD patterns for KFO-20 after four cycles.

Author Contributions: Conceptualisation, Z.G.; software, J.J.; visualisation, Y.H.; investigation, Z.L.; data curation, X.L.; writing—original-draft preparation, X.Z.; writing-review and editing, H.Y. All authors have read and agreed to the published version of the manuscript.

Funding: This research was supported by funds granted by the Natural Science Foundation of Liaoning Province of China (2019-ZD-0481) and the Project of Education Office of Liaoning Province (LQN201909).

Acknowledgments: This work was financially supported by the State Key Laboratory of Inorganic Synthesis and Preparative Chemistry, the Natural Science Foundation of Liaoning Province of China (2019-ZD-0481), and the Project of Education Office of Liaoning Province (LQN201909).

Conflicts of Interest: The authors declare no conflict of interest.

\section{References}

1. Jegatheesan, V.; Pramanik, B.K.; Chen, J.Y.; Navaratna, D.; Chang, C.Y.; Shu, L. Treatment of textile wastewater with membrane bioreactor: A critical review. Bioresour. Technol. 2016, 204, 202-212. [CrossRef] [PubMed]

2. Megala, S.; Prabhu, S.; Harish, S.; Navaneethan, M.; Sohila, S.; Ramesh, R. Enhanced photocatalytic dye degradation activity of carbonate intercalated layered $\mathrm{Zn}, \mathrm{ZnNi}$ and $\mathrm{ZnCu}$ hydroxides. Appl. Surf. Sci. 2019, 481, 385-393. [CrossRef]

3. Phaltane, S.A.; Vanalakar, S.A.; Bhat, T.S.; Patil, P.S.; Sartale, S.D.; Kadam, L.D. Photocatalytic degradation of methylene blue by hydrothermally synthesized CZTS nanoparticles. J. Mater. Sci. Mater. Electron. 2017, 28, 8186-8191. [CrossRef]

4. Hachem, C.; Bocquillon, F.; Zahraa, O.; Bouchy, M. Decolourization of textile industry wastewater by the photocatalytic degradation process. Dyes Pigments 2001, 49, 117-125. [CrossRef]

5. Zhou, T.; Lu, X.H.; Wang, J.; Wong, F.S.; Li, Y.Z. Rapid decolorization and mineralization of simulated textile wastewater in a heterogeneous Fenton like system with/without external energy. J. Hazard. Mater. 2009, 165, 193-199. [CrossRef] [PubMed]

6. Mahamallik, P.; Pal, A. Degradation of textile wastewater by modified photo-Fenton process: Application of $\mathrm{Co}$ (II) adsorbed surfactant-modified alumina as heterogeneous catalyst. J. Environ. Chem. Eng. 2017, 5, 2886-2893. [CrossRef]

7. Moreira, F.C.; Boaventura, R.A.R.; Brillas, E.; Vilar, V.J.P. Electrochemical advanced oxidation processes: A review on their application to synthetic and real wastewaters. Appl. Catal. B Environ. 2017, 202, 217-261. [CrossRef]

8. Babuponnusami, A.; Muthukumar, K. A review on Fenton and improvements to the Fenton process for wastewater treatment. J. Environ. Chem. Eng. 2014, 2, 557-572. [CrossRef]

9. Gogate, P.R.; Pandit, A.B. A review of imperative technologies for wastewater treatment II: Hybrid methods. Adv. Environ. Res. 2004, 8, 553-597. [CrossRef]

10. El-Khouly, S.M.; Fathy, N. Multi-walled carbon nanotubes supported amorphous $\mathrm{Fe}_{2} \mathrm{O}_{3}$ and $\mathrm{Ag}_{2} \mathrm{O}-\mathrm{Fe}_{2} \mathrm{O}_{3}$ as Fenton catalysts for degradation of maxilon red dye. Asia-Pac. J. Chem. Eng. 2018, 13, e2184. [CrossRef]

11. Teodoro, A.; Boncz, M.Á.; Júnior, A.M.; Paulo, P.L. Disinfection of greywater pre-treated by constructed wetlands using photo-Fenton: Influence of $\mathrm{pH}$ on the decay of Pseudomonas aeruginosa. J. Environ. Chem. Eng. 2014, 2, 958-962. [CrossRef]

12. Guo, X.; Wang, D. Photo-Fenton degradation of methylene blue by synergistic action of oxalic acid and hydrogen peroxide with $\mathrm{NiFe}_{2} \mathrm{O}_{4}$ hollow nanospheres catalyst. J. Environ. Chem. Eng. 2019, 7, 102814. [CrossRef] 
13. Wang, Y.B.; Zhao, H.Y.; Li, M.F.; Fan, J.Q.; Zhao, G.H. Magnetic ordered mesoporous copper ferrite as a heterogeneous Fenton catalyst for the degradation of imidacloprid. Appl. Catal. B Environ. 2014, 147, 534-545. [CrossRef]

14. Zhang, Y.M.; Zhang, N.S.; Wang, T.T.; Huang, H.T.; Chen, Y.; Li, Z.S.; Zou, Z.G. Heterogeneous degradation of organic contaminants in the photo-Fenton reaction employing pure cubic $\beta-\mathrm{Fe}_{2} \mathrm{O}_{3}$. Appl. Catal. B Environ. 2019, 245, 410-419. [CrossRef]

15. Hu, Z.; Oh, W.-D.; Liu, Y.; Yang, E.-H.; Lim, T.-T. Controllable mullite bismuth ferrite micro/nanostructures with multifarious catalytic activities for switchable/hybrid catalytic degradation processes. J. Colloid. Interf. Sci. 2018, 509, 502-514. [CrossRef]

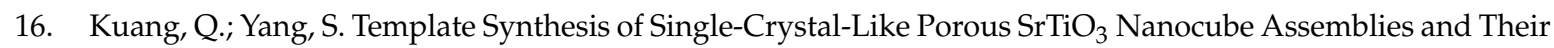
Enhanced Photocatalytic Hydrogen Evolution. ACS Appl. Mater. Interfaces. 2013, 5, 3683-3690. [CrossRef]

17. Chou, T.P.; Zhang, Q.; Russo, B.; Fryxell, G.E.; Cao, G. Titania Particle Size Effect on the Overall Performance of Dye-Sensitized Solar Cells. J. Phys. Chem. C 2007, 111, 6296-6302. [CrossRef]

18. Wang, J.; Inada, H.; Wu, L.; Zhu, Y.; Choi, Y.; Liu, P.; Zhou, W.-P.; Adzic, R.R. Oxygen Reduction on Well-Defined Core-Shell Nanocatalysts: Particle Size, Facet, and Pt Shell Thickness Effects. J. Am. Chem. Soc. 2009, 131, 17298-17302. [CrossRef]

19. Kango, S.; Kalia, S.; Celli, A.; Njuguna, J.; Habibi, Y.; Kumar, R. Surface modification of inorganic nanoparticles for development of organic-inorganic nanocomposites-A review. Prog. Polym. Sci. 2013, 38, 1232-1261. [CrossRef]

20. Verma, A.; Stellacci, F. Effect of Surface Properties on Nanoparticle-Cell Interactions. Small 2010, 6, 12-21. [CrossRef]

21. Huang, X.P.; Chen, Y.; Walter, E.; Zong, M.R.; Wang, Y.; Zhang, X.; Qafoku, O.; Wang, Z.M.; Rosso, K.M. Facet-Specific Photocatalytic Degradation of Organics by Heterogeneous Fenton Chemistry on Hematite Nanoparticles. ACS Catal. 2019, 53, 10197-10207. [CrossRef] [PubMed]

22. Chen, C.Q.; Duan, F.F.; Zhao, S.C.; Wang, W.K.; Yang, F.; Nuansingc, W.; Zhang, B.Y.; Qin, Y.; Knez, M. Porous $\mathrm{Fe}_{2} \mathrm{O}_{3}$ nanotubes with $\alpha-\gamma$ phase junction for enhanced charge separation and photocatalytic property produced by molecular layer deposition. Appl. Catal. B Environ. 2019, 248, 218-225. [CrossRef]

23. Huang, Y.; Han, C.; Liu, Y.Q.; Nadagouda, M.N.; Machala, L.; O'Shea, K.E.; Sharma, V.K.; Dionysiou, D.D. Degradation of atrazine by $\mathrm{Zn}_{\mathrm{x}} \mathrm{Cu}_{1-\mathrm{x}} \mathrm{Fe}_{2} \mathrm{O}_{4}$ nanomaterial-catalyzed sulfite under UV-vis light irradiation: Green strategy to generate $\mathrm{SO}_{4}{ }^{-}$. Appl. Catal. B Environ. 2018, 221, 380-392. [CrossRef]

24. Rusevova, K.; Köferstein, R.; Rosell, M.; Richnow, H.H.; Kopinke, F.-D.; Georgi, A. $\mathrm{LaFeO}_{3}$ and $\mathrm{BiFeO}_{3}$ perovskites as nanocatalysts for contaminant degradation in heterogeneous Fenton-like reactions. Chem. Eng. J. 2014, 239, 322-331. [CrossRef]

25. Hu, Z.T.; Chen, Z.; Goei, R.; Wu, W.Y.; Lim, T.K. Magnetically recyclable Bi/Fe-based hierarchical nanostructures via self-assembly for environmental decontamination. Nanoscale 2016, 8, 12736-12746. [CrossRef]

26. Yao, Y.J.; Cai, Y.M.; Lu, F.; Wei, F.Y.; Wang, X.Y.; Wang, S.B. Magnetic recoverable $\mathrm{MnFe}_{2} \mathrm{O}_{4}$ and $\mathrm{MnFe}_{2} \mathrm{O}_{4}$-graphene hybrid as heterogeneous catalysts of peroxymonosulfate activation for efficient degradation of aqueous organic pollutants. J. Hazard. Mater. 2014, 270, 61-70. [CrossRef] [PubMed]

27. Jauhar, S.; Singhal, S.; Dhiman, M. Manganese substituted cobalt ferrites as efficient catalysts for $\mathrm{H}_{2} \mathrm{O}_{2}$ assisted degradation of cationic and anionic dyes: Their synthesis and characterization. Appl. Catal. A Gen. 2014, 486, 210-218. [CrossRef]

28. Chen, W.; Xiong, L.S.; Chen, F.X. Solvothermal synthesis of sub-200 nm Fe3O4 submicrospheres with enhanced catalytic performances by using acicular goethite as solid precursor. Micro Nano Lett. 2017, 9, 711-713. [CrossRef]

29. Zhu, J.N.; Zhu, X.Q.; Cheng, F.F.; Li, P.; Wang, F.; Xiao, Y.W.; Xiong, W.W. Preparing copper doped carbon nitride from melamine templated crystalline copper chloride for Fenton-like catalysis. Appl. Catal. B Environ. 2019, 256, 117830. [CrossRef]

30. Borthakur, S.; Saikia, L. $\mathrm{ZnFe}_{2} \mathrm{O}_{4} @ g-\mathrm{C}_{3} \mathrm{~N}_{4}$ nanocomposites: An efficient catalyst for Fenton-like photodegradation of environmentally pollutant Rhodamine B. J. Environ. Chem. Eng. 2019, 7, 103035. [CrossRef] 
31. Huang, S.Q.; Zhang, Q.; Liu, P.Y.; Ma, S.J.; Xie, B.; Yang, K.; Zhao, Y.P. Novel up-conversion carbon quantum dots $/ \alpha$-FeOOH nanohybrids eliminate tetracycline and its related drug resistance in visible-light responsive Fenton system. Appl. Catal. B Environ. 2019, 263, 118336. [CrossRef]

32. Liu, Y.Y.; Jin, W.; Zhao, Y.P.; Zhang, G.S.; Zhang, W. Enhanced catalytic degradation of methylene blue by $\alpha-\mathrm{Fe}_{2} \mathrm{O}_{3} /$ graphene oxide via heterogeneous photo-Fenton reactions. Appl. Catal. B Environ. 2017, 206, 642-652. [CrossRef]

33. Wang, L.L.; Zhu, Y.; Yang, D.; Zhao, L.; Ding, H.M.; Wang, Z.H. The mixed marriage of copper and carbon ring-g- $\mathrm{C}_{3} \mathrm{~N}_{4}$ nanosheet: A visible-light-driven heterogeneous Fenton-like catalyst. Appl. Surf. Sci. 2019, 488, 728-738. [CrossRef]

34. Yuan, H.M.; Li, H.; Zhang, T.S.; Li, G.H.; He, T.M.; Du, F.; Feng, S.H. A $\mathrm{K}_{2} \mathrm{Fe}_{4} \mathrm{O}_{7}$ superionic conductor for all-solid-state potassium metal batteries. J. Mater. Chem. A 2018, 6, 8413-8418. [CrossRef]

35. Zhou, J.; Liu, X.; Hu, F.L.; Zou, H.H.; Li, X.J. A new 1-D extended vanadoborate containing triply bridged metal complex units. Inorg. Chem. Commun 2012, 25, 51-54. [CrossRef]

36. Guo, X.J.; Wang, K.B.; Li, D.; Jia, J.B. Heterogeneous photo-Fenton processes using graphite carbon coating hollow $\mathrm{CuFe}_{2} \mathrm{O}_{4}$ spheres for the degradation of methylene blue. Appl. Surf. Sci. 2017, 420, 792-801. [CrossRef]

37. Wongso, V.; Chen, C.J.; Razzaq, A.; Kamal, N.A.; Sambudi, N.S. Hybrid kaolin/TiO 2 composite: Effect of urea addition towards an efficient photocatalyst for dye abatement under visible light irradiation. Appl. Clay Sci. 2019, 180, 105158. [CrossRef]

38. Wolski, L.; Walkowiak, A.; Ziolek, M. Formation of reactive oxygen species upon interaction of Au/ZnO with $\mathrm{H}_{2} \mathrm{O}_{2}$ and their activity in methylene blue degradation. Catal. Today 2019, 333, 54-62. [CrossRef]

39. Wang, X.T.; Zhou, J.Q.; Zhao, S.; Chen, X.; Yu, Y. Synergistic effect of adsorption and visible-light photocatalysis for organic pollutant removal over $\mathrm{BiVO}_{4} /$ carbon sphere nanocomposites. Appl. Surf. Sci. 2018, 453, $394-404$. [CrossRef]

40. Wang, D.J.; Shen, H.D.; Guo, L.; Wang, C.; Fu, F. Porous BiOBr/ $\mathrm{Bi}_{2} \mathrm{MoO}_{6}$ Heterostructures for Highly Selective Adsorption of Methylene Blue. ACS Omega. 2016, 1, 566-577. [CrossRef]

41. Brown, I.D.; Altermatt, D. Bond-valence parameters obtained from a systematic analysis of the Inorganic Crystal Structure Database. Acta Crystallogr. Sect. B Struct. Sci. 1985, 41, 244-247. [CrossRef]

42. Keene, T.D.; D’Alessandro, D.M.; Krämer, K.W.; Price, J.R.; Price, D.J.; Decurtins, S.; Kepert, C.J. $\left[\mathrm{V}_{16} \mathrm{O}_{38}(\mathrm{CN})\right]^{9-}$ : A Soluble Mixed-Valence Redox-Active Building Block with Strong Antiferromagnetic Coupling. Inorg. Chem. 2012, 51, 9192-9199. [CrossRef] [PubMed]

43. Sun, Y.J.; Yan, Y.; Wang, Y.Y.; Li, Y.; Li, J.Y.; Yu, J.H. High proton conduction in a new alkali metal-templated open-framework aluminophosphate. Chem. Commun. 2015, 51, 9317-9319. [CrossRef] [PubMed]

44. Gui, D.X.; Zheng, T.; Xie, J.; Cai, Y.W.; Wang, Y.X.; Chen, L.H.; Diwu, J.; Chai, Z.F.; Wang, S. Significantly Dense Two-Dimensional Hydrogen-Bond Network in a Layered Zirconium Phosphate Leading to High Proton Conductivities in Both Water-Assisted Low-Temperature and Anhydrous Intermediate-Temperature Regions. Inorg. Chem. 2016, 55, 12508-12511. [CrossRef] [PubMed]

45. Slade, R.C.T.; Hardwick, A.; Dickens, P.G. Investigation of $\mathrm{H}+$ motion in NAFION film by pulsed 1H NMR and A.C. conductivity measurements. Solid State Ion. 1983, 9, 1093-1098. [CrossRef]

46. Bernard, L.; Fitch, A.; Wright, A.F.; Fender, B.E.F.; Howe, A.T. Mechanisms of hydrogen diffusion and conduction in $\mathrm{DUO}_{2} \mathrm{AsO}_{4} \cdot 4 \mathrm{D}_{2} \mathrm{O}$ as inferred from neutron diffraction evidence. Solid State Ion. 1981, 5, 459-462. [CrossRef]

47. Dey, C.; Kundu, T.; Banerjee, R. Reversible phase transformation in proton conducting Strandberg-type POM based metal organic material. Chem. Commun. 2012, 48, 266-268. [CrossRef]

48. Yang, T.; Sun, J.L.; Eriksson, L.; Li, G.B.; Zou, X.D.; Liao, F.H.; Lin, J.H. Na5[ $\left.\mathrm{MB}_{24} \mathrm{O}_{34}(\mathrm{OH})_{12}\right] \cdot \mathrm{nH}_{2} \mathrm{O}\left(\mathrm{M}=\mathrm{Cr}{ }^{3+}\right.$, $\mathrm{Al}^{3+}$ ): Unprecedented Spherelike Polyborate Clusters from Boric Acid Flux Synthesis. Inorg. Chem. 2008, 47, 3228-3233. [CrossRef]

(C) 2020 by the authors. Licensee MDPI, Basel, Switzerland. This article is an open access article distributed under the terms and conditions of the Creative Commons Attribution (CC BY) license (http://creativecommons.org/licenses/by/4.0/). 